\title{
Sistem Informasi Penyewaan Lapangan Bulu Tangkis di Gedung Olahraga AUB Surakarta Berbasis Android
}

\author{
Isadora Nugroho*1, Robby Rachmatullah ${ }^{2}$, Ilnayati Simanjuntak ${ }^{3}$ \\ ${ }^{1,2,3}$ Program Studi Sistem Informasi, STMIK AUB, Surakarta, Indonesia \\ e-mail: *1isadora.nugroho@stmik-aub.ac.id, ${ }^{2}$ robby_r@stmik-aub.ac.id, \\ 32167100874@student.stmik-aub.ac.id
}

\begin{abstract}
Abstrak
Gedung Olahraga AUB Surakarta adalah sebuah usaha yang bergerak dibisnis penyewaan lapangan bulu tangkis, masih menggunakan sistem manual yaitu pelanggan datang langsung kelokasi untuk menanyakan informasi jadwal penyewaan lapangan, lalu akan memesan jika tersedia lapangan yang kosong, transaksi akan dilakukan ketika calon penyewa datang pada jadwal yang telah ditentukan. Untuk membantu proses transaksi penyewaan maka dibuatkan sistem yang mampu mengolah transaksi penyewaan secara online, dan mempermudah pelanggan dalam mendapatkan informasi jadwal lapangan, informasi harga sewa dan dapat melakukan pemesanan secara online. Hasil perancangan sistem informasi pemesanan ini menggunakan metode pengembangan sistem waterfall. Untuk analisa kelemahan sistem menggunakan analisa PIECES (Perfomance, Information, Economy, Cotrol, Efficiency, dan Service).Sedangkan untuk menggambarkan alur data menggunakan yang terdiriflowchart sistem, usecase diagram, activity diagram, sequence diagram dan class diagram. Berdasarkan pengujian yang telah dilakukan menggunakan blackbox testing, sistem yang dibangun dapat membantu masalah yang dihadapi pengelola Gedung Olahraga AUB.
\end{abstract}

Kata kunci-Gedung olahraga AUB, Informasi penyewaan, Bulu tangkis, Android

\begin{abstract}
The AUB Surakarta Sports Building is a business engaged in the badminton court rental business, still using a manual system, where customers come directly to the location to ask for field rental information, then order if an empty field is available, the transaction will be carried out when the prospective tenant arrives at the scheduled schedule. determined. To assist the rental transaction process, a system is created that is able to process rental transactions online, and makes it easier for customers to get field schedule information, rental price information and be able to place online orders. The results of this ordering information system design use the waterfall system development method. For system weakness analysis using PIECES analysis (Performance, Information, Economy, Control, Efficiency, and Service). Meanwhile, to describe the data flow using a system flowchart, usecase diagrams, activity diagrams, sequence diagrams and class diagrams. Based on tests that have been done using blackbox testing, the system built can help problems faced by the AUB Sports Building manager.
\end{abstract}

Keywords - Sports hall, rental information, badminton, android

\section{PENDAHULUAN}

Perkembangan Teknologi Informasi kini membuat hidup manusia yang serba cepat, simpel dan mudah. Teknologi memudahkan manusia untuk menunjang segala aktivitas kehidupan mulai dari urusan pekerjaan di kantor, rumah tangga, pelayanan publik bahkan 
olahraga. Untuk itu diperlukan adanya pengembangan yang memanfaatkan perangkat android. Android itu sendiri merupakan sebuah sistem operasi pada smartphone yang bersifat terbuka. Android bisa digunakan oleh setiap orang yang ingin menggunakannya pada perangkat mereka. Android menyediakan platform terbuka bagi para pengembang untuk menciptakan aplikasi mereka sendiri yang akan digunakan untuk bermacam peranti gerak, (Safaat, 2012). Saat ini smartphone juga dapat bermanfaat di dalam berbagai bidang, seperti hiburan, pemerintahan dan bisnis.

Didalam sebuah perusahaan atau bidang bisnis baik kecil, menengah, maupun berskala besar, biasanya perlu menggunakan sebuah sistem informasi yang menunjang kegiatan perusahaan maupun usaha bisnis tersebut. Dengan adanya sistem informasi tersebut maka segala sesuatu kegiatan dapat terkontrol satu sama lain dengan baik. Sistem pemesanan atau penyewaan pada umumnya digunakan oleh perusahaan untuk memberikan pelayanan pada penggunanya, dimana dalam proses penyewaan akan mempercepat proses pesanan pelanggan. Hal ini akan mengefisiensikan waktu yang digunakan untuk melayani pelanggan yang datang secara langsung.

Bulu Tangkis adalah kegiatan yang banyak diminati masyarakat, semua kalangan dari berbagai umur pun gemar dengan olahraga bulu tangkis. Banyaknya penggemar olahraga bulu tangkis ini sehingga menjadikan peluang bisnis yang sangat menjanjikan. Tidak mengherankan apabila saat ini banyak dijumpai tempat penyewaan lapangan Bulu Tangkis dimana-mana.

Gedung Olahraga AUB Surakarta adalah sebuah usaha yang bergerak dibisnis penyewaan lapangan bulu tangkis. Namun dalam proses pemesanan masih menggunakan sistem manual yaitu penyewa harus datang terlebih dahulu kelokasi untuk menanyakan jadwal yang tersedia kepada pengelola dan melakukan pemesanan setelah menentukan jadwal. Untuk proses pembayaran penyewa harus membayar uang muka (DP) sebagai bukti bahwa telah memesan lapangan dan akan membayar penuh jika telah selesai menggunakan lapangan. Sedangkan untuk pengelola masih menggunakan pencatatan secara tertulis untuk mencatat nama-nama member dan non member beserta jadwal yang telah digunakan, yang pada saat ini member berjumlah 60 penyewa dan non member sekitar 45 penyewa perbulannya. Pengelola juga menggunakan catatan untuk melihat hasil laporan pendapatan dan pengeluaran setiap bulan.

Kendala yang dialami saat ini yaitu sulitnya akses pelanggan dalam melakukan pemesanan lapangan dan bagi pengelola dalam mengelola laporan. Melihat hal tersebut, penulis bermaksud untuk merancang dan membangun aplikasi penyewaan lapangan bulu tangkis berbasis android. Dimana setiap orang bisa melihat dan memesan secara online. Dengan sistem yang akan dibuat diharapkan bisa memberikan informasi kepada pelanggan sehingga kendala yang dialami bisa diselasaikan.

\section{METODE PENELITIAN}

\subsection{Metode Pengujian Sistem Blackbox Testing}

Tahap ini peneliti akan melakukan pengujian menggunakan sekumpulan aktifitas validasi, dengan pendekatan blackboxtesting. Black-box testing adalah metode pengujian perangkat lunak yang tes fungsionalitas dari aplikasi yang bertentangan dengan struktur internal atau kerja. Uji kasus dibangun di sekitar spesifikasi dan persyaratan yakni, aplikasi apa yang seharusnya dilakukan. Menggunakan deskripsi eksternal perangkat lunak, termasuk spesifikasi, persyaratan, dan desain untuk menurunkan uji kasus. Tes ini dapat menjadi fungsional atau non-fungsional. Perancang uji memilih input yang valid dan tidak valid dan menentukan output yang benar, (Pressman, 2001).

\subsection{Flowchart Sistem}

Gambar flowchart sistem penyewaan yang akan dibangun pada gedung olahraga AUB dapat dilihat pada Gambar 1. 


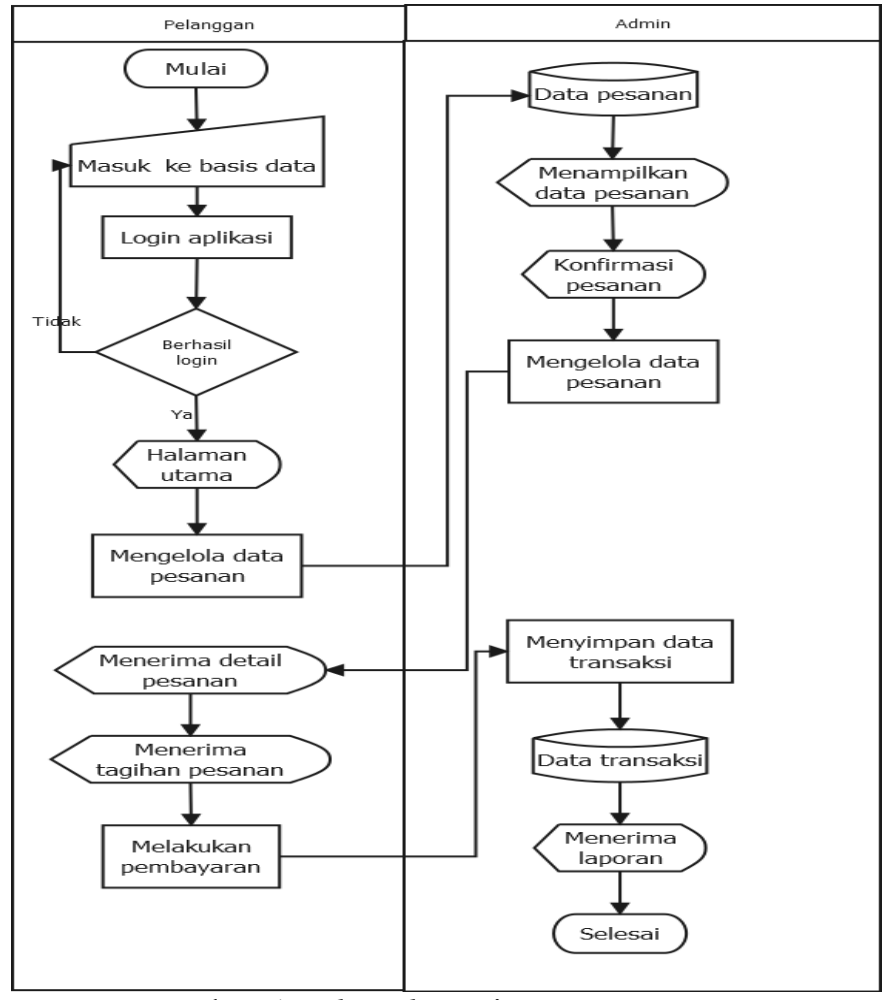

Gambar 1. Flowchart sistem penyewaan

Pada flowchart Gambar 1, pengguna yang akan mencari data ketersediaan lapangan dengan memasukan jumlah lapangan yang akan disewa, lama waktu penyewaan, tanggal akan menggunakan lapangan serta sistem pembayaran yang akan digunakan, kemudian sistem membaca dan mencari data yang diperlukan yang sudah tercantum dalam data base. Jika data yang dicari ditemukan maka, data akan ditampilkan. Namun ketika data tidak ditemukan maka pencarian selesai, dan pengguna dapat melakukan pencarian ulang dengan memasukkan data yang baru.

\subsection{Use Case Diagram}

Use Case Diagram memperlihatkan himpunan use case dan aktor-aktor. Use case diagram sangat penting untuk mengorganisasi dan memodelkan perilaku dari suatu sistem yang dibutuhkan serta diharapkan pengguna.

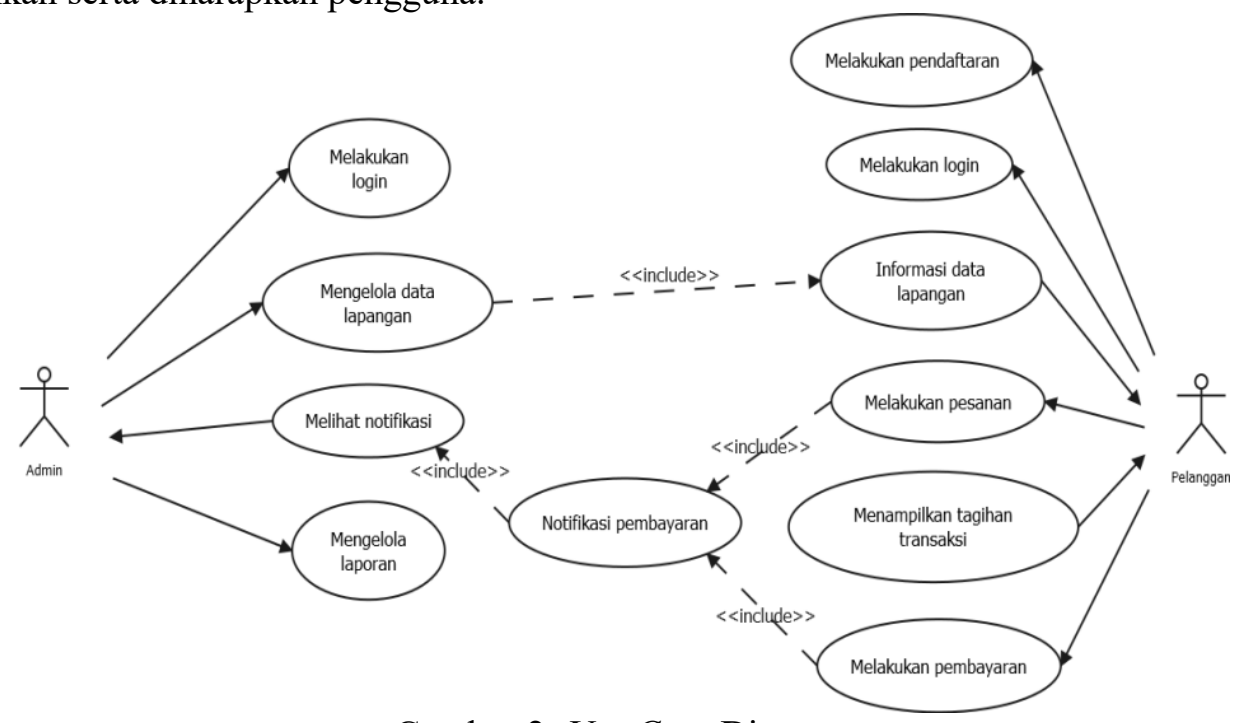

Gambar 2. Use Case Diagram 
Usecase Diagram Gambar 2 pengelola melakukan login ke dalam sistem dengan menggunakan username dan password. Setelah login kedalam sistem dan mengelola aplikasi. Mulai dari mengelola data lapangan, data pemesanan, data pelanggan, dan data transaksi pelanggan. Sedangkan untuk pelanggan membuka aplikasi untuk mencari informasi data lapangan, melakukan pemesanan secara online dan pembayaran secara online.

Dari Usecase diatas ada 2 aktor yang memiliki peran masing-masing yaitu:

a. Admin adalah actor yang mengelola semua data dan menerima laporan dari aplikasi serta pengelola aplikasi yang berhak meng-up grade aplikasi

b. Pelanggan adalah actor yang menggunakan aplikasi ini untuk melihat jadwal lapangan atau melakukan pemesanan

\subsection{Activity Diagram}

Activity Diagram menggambarkan aluran proses yang tedapat dalam mulai aktivitas start sampai aktivitas berhenti. Activity Diagram mendeskripsikan aksi-aksi dan hasilnya. Berikut ini Gambar 3 adalah Activity diagram yang digunakan pada peneltian ini:

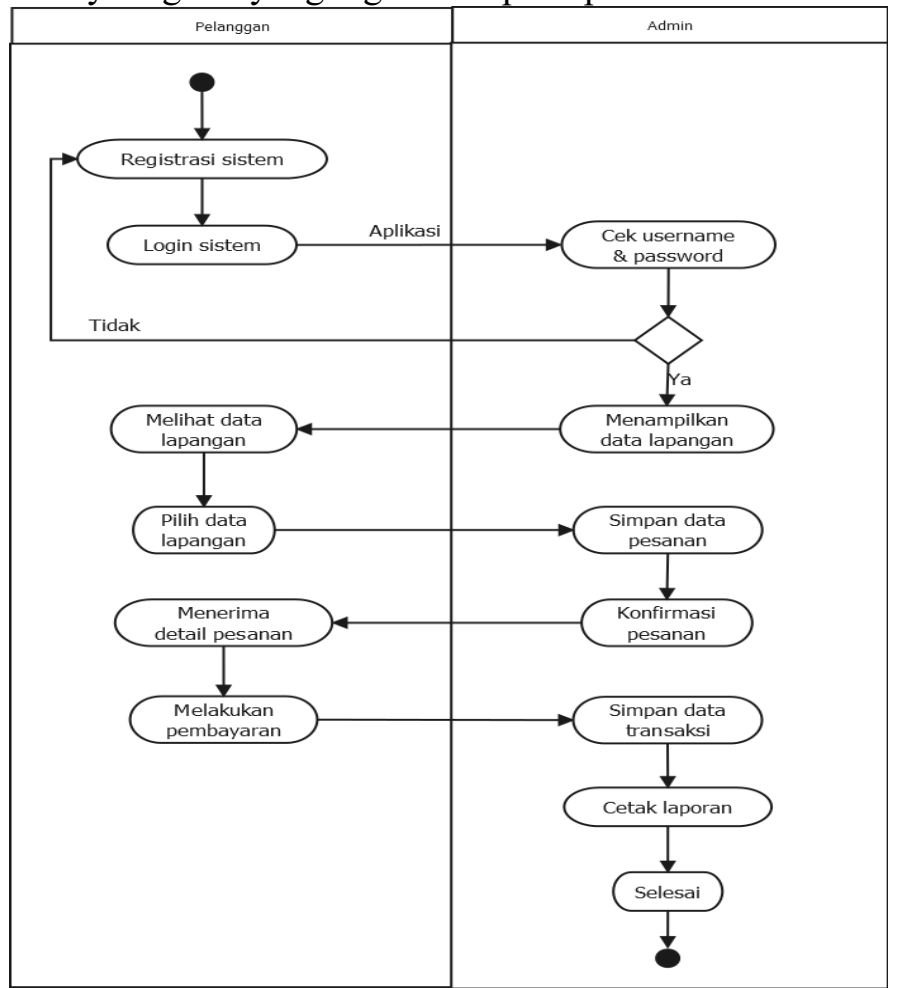

Gambar 3. Activity Diagram

Activity diagram Gambar 3 menunjukkan pada saat pengguna akan menggunakan aplikasi harus memasukkan userid dan password, yang kemudian akan dicek oleh sistem, jika userid dan password benar, maka pengguna akan melihat tampilan halaman utama dan selanjutnya dapat menggunakan aplikasi untuk mencari lapangan yang dapat digunakan/ disewa yang diinginkan. Pada kejadian userid dan password salah, sistem akan menolak menampilkan halaman utama dan dialihak ke halaman login, hingga pengguna memasukkan userid dan password yang betul.

\subsection{Class Diagram}

Class diagram adalah diagram yang digunakan untuk menampilkan beberapa kelas serta paket-paket yang ada dalam sistem atau perangkat lunak yang sedang dikembangkan. Class diagram memberikan gambaran atau diagram statis tentang sistem atau perangkat lunak dan relasi-relasi yang ada didalamnya. 


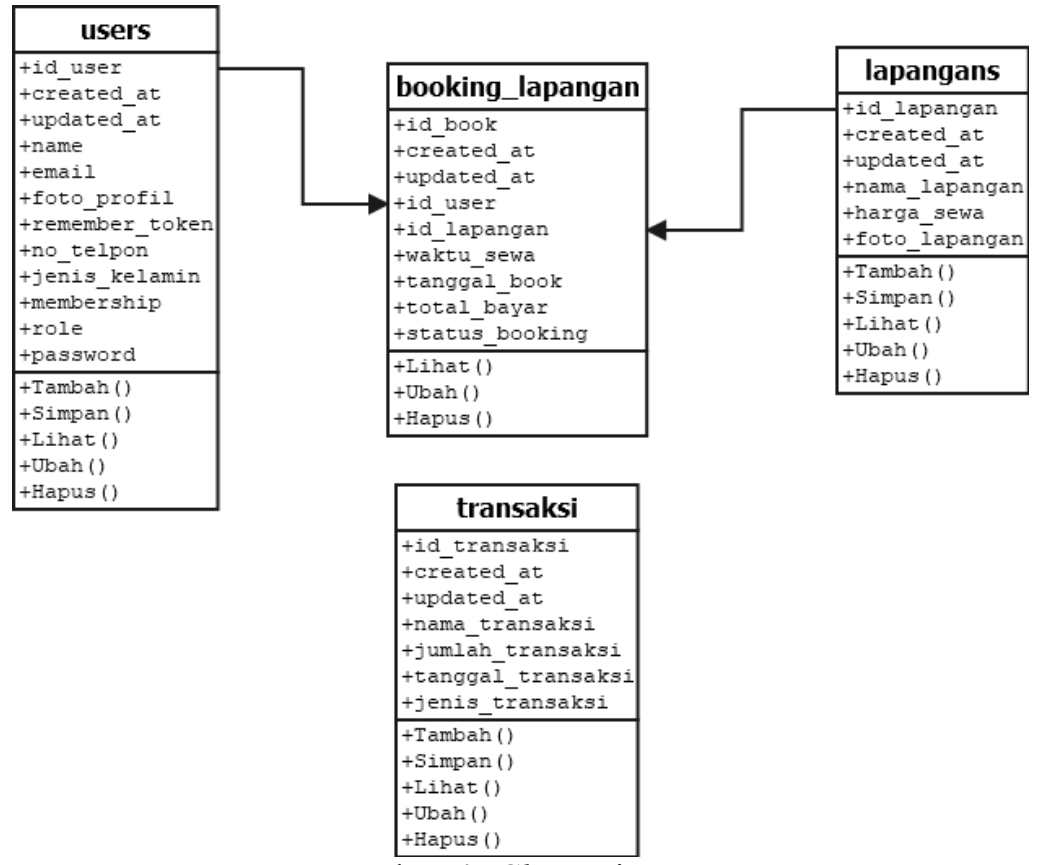

Gambar 4. Class Diagram

\section{HASIL DAN PEMBAHASAN}

\subsection{Implementasi}

Pada bagian ini menguraikan tentang tahapan-tahapan dalam melakukan pengujian terhadap sistem dan program yang sudah dibuat, sehingga sistem tersebut bebas dari kesalahan agar dapat dilanjutkan pada proses selanjutnya yaitu implementasi sistem dengan menggunakan blackbox testing sebagai metode pengujian sistem, seperti pada Tabel 1 berikut.

Tabel 1. Pengujian blackbox testing sistem

\begin{tabular}{|c|l|l|l|l|c|}
\hline No. & $\begin{array}{l}\text { Fungsi Yang } \\
\text { Diuji }\end{array}$ & \multicolumn{1}{|c|}{$\begin{array}{c}\text { Data } \\
\text { Masukan }\end{array}$} & $\begin{array}{l}\text { Hasil Yang } \\
\text { Diharapkan }\end{array}$ & \multicolumn{1}{|c|}{ Pengamatan } & Kesimpulan \\
\hline 1 & $\begin{array}{l}\text { Halaman } \\
\text { login admin } \\
\text { dan user }\end{array}$ & $\begin{array}{l}\text { Klik menu } \\
\text { masuk }\end{array}$ & $\begin{array}{l}\text { Memasukkan dan } \\
\text { username dan } \\
\text { password }\end{array}$ & $\begin{array}{l}\text { Sistem berhasil } \\
\text { masuk kehalaman } \\
\text { utama }\end{array}$ & Valid \\
\hline $\begin{array}{l}\text { Halaman } \\
\text { profil admin }\end{array}$ & $\begin{array}{l}\text { Klik menu } \\
\text { profil }\end{array}$ & $\begin{array}{l}\text { Memasukkan } \\
\text { foto profil dan } \\
\text { menampilkan } \\
\text { foto profil }\end{array}$ & $\begin{array}{l}\text { Sistem berhasil } \\
\text { memasukkan foto } \\
\text { profil dan } \\
\text { menampilkan foto } \\
\text { profil }\end{array}$ & Valid \\
\hline 3 & $\begin{array}{l}\text { Menu } \\
\text { dashboard }\end{array}$ & $\begin{array}{l}\text { Klik menu } \\
\text { dashboard }\end{array}$ & $\begin{array}{l}\text { Menampilkan } \\
\text { notifikasi, jumlah } \\
\text { member, jumlah } \\
\text { pengeluaran, } \\
\text { jumlah } \\
\text { pemasukan. }\end{array}$ & $\begin{array}{l}\text { Sistem berhasil } \\
\text { menampilkan } \\
\text { notifikasi, jumlah } \\
\text { member, jumlah } \\
\text { pengeluaran, } \\
\text { jumlah } \\
\text { pemasukan. }\end{array}$ & Valid \\
\hline 4 & $\begin{array}{l}\text { Menu data } \\
\text { master }\end{array}$ & $\begin{array}{l}\text { Klik menu } \\
\text { data master }\end{array}$ & $\begin{array}{l}\text { Menampilkan } \\
\text { halaman } \\
\text { lapangan dan user }\end{array}$ & $\begin{array}{l}\text { Sistem berhasil } \\
\text { menampilkan } \\
\text { halaman lapangan } \\
\text { dan user }\end{array}$ & Valid \\
\hline 5 & $\begin{array}{l}\text { Menu } \\
\text { halaman }\end{array}$ & $\begin{array}{l}\text { Klik menu } \\
\text { lapangan }\end{array}$ & $\begin{array}{l}\text { Menampilkan } \\
\text { data lapangan }\end{array}$ & $\begin{array}{l}\text { Sistem berhasil } \\
\text { menambah data }\end{array}$ & Valid \\
\hline
\end{tabular}




\begin{tabular}{|c|c|c|c|c|c|}
\hline & lapangan & & & lapangan & \\
\hline 6 & $\begin{array}{l}\text { Tambah data } \\
\text { lapangan }\end{array}$ & $\begin{array}{l}\text { Klik menu } \\
\text { add new }\end{array}$ & $\begin{array}{l}\text { Memasukkan } \\
\text { data lapangan }\end{array}$ & $\begin{array}{l}\text { Sistem berhasil } \\
\text { menyimpan data } \\
\text { lapangan }\end{array}$ & Valid \\
\hline 7 & $\begin{array}{l}\text { Menu lihat } \\
\text { data lapangan }\end{array}$ & $\begin{array}{l}\text { Klik menu } \\
\text { view }\end{array}$ & $\begin{array}{l}\text { Menampilkan } \\
\text { data lapangan }\end{array}$ & $\begin{array}{l}\text { Sistem berhasil } \\
\text { menampilkan data } \\
\text { lapangan }\end{array}$ & Valid \\
\hline 8 & $\begin{array}{l}\text { Edit data } \\
\text { lapangan }\end{array}$ & $\begin{array}{l}\text { Klik menu } \\
\text { edit }\end{array}$ & $\begin{array}{l}\text { Mengubah data } \\
\text { lapangan }\end{array}$ & $\begin{array}{l}\text { Sistem berhasil } \\
\text { mengubah data } \\
\text { lapangan }\end{array}$ & Valid \\
\hline 9 & $\begin{array}{l}\text { Hapus data } \\
\text { lapangan }\end{array}$ & $\begin{array}{l}\text { Klik menu } \\
\text { delete }\end{array}$ & $\begin{array}{l}\text { Menghapus data } \\
\text { lapangan }\end{array}$ & $\begin{array}{l}\text { Sistem berhasil } \\
\text { menghapus data } \\
\text { lapangan }\end{array}$ & Valid \\
\hline 10 & $\begin{array}{l}\text { Menu } \\
\text { halaman user }\end{array}$ & $\begin{array}{l}\text { Klik menu } \\
\text { user }\end{array}$ & $\begin{array}{l}\text { Menampilkan } \\
\text { data user }\end{array}$ & $\begin{array}{l}\text { Sistem berhasil } \\
\text { menambah data } \\
\text { user }\end{array}$ & Valid \\
\hline 11 & $\begin{array}{l}\text { Tambah data } \\
\text { user }\end{array}$ & $\begin{array}{l}\text { Klik menu } \\
\text { add new }\end{array}$ & $\begin{array}{l}\text { Masukkan data } \\
\text { user }\end{array}$ & $\begin{array}{l}\text { Sistem berhasil } \\
\text { menyimpan data } \\
\text { user }\end{array}$ & Valid \\
\hline 12 & $\begin{array}{l}\text { Menu lihat } \\
\text { data user }\end{array}$ & $\begin{array}{l}\text { Klik menu } \\
\text { view }\end{array}$ & $\begin{array}{l}\text { Menampilkan } \\
\text { data user }\end{array}$ & $\begin{array}{l}\text { Sistem berhasil } \\
\text { menampilkan data } \\
\text { user }\end{array}$ & Valid \\
\hline 13 & Edit data user & $\begin{array}{l}\text { Klik menu } \\
\text { edit }\end{array}$ & $\begin{array}{l}\text { Mengubah data } \\
\text { user }\end{array}$ & $\begin{array}{l}\text { Sistem berhasil } \\
\text { mengubah data } \\
\text { user }\end{array}$ & Valid \\
\hline 14 & $\begin{array}{l}\text { Hapus data } \\
\text { user }\end{array}$ & $\begin{array}{l}\text { Klik menu } \\
\text { delete }\end{array}$ & $\begin{array}{l}\text { Menghapus data } \\
\text { user }\end{array}$ & $\begin{array}{l}\text { Sistem berhasil } \\
\text { menghapus data } \\
\text { user }\end{array}$ & Valid \\
\hline 15 & $\begin{array}{l}\text { Menu data } \\
\text { transaksi }\end{array}$ & $\begin{array}{l}\text { Klik menu } \\
\text { data } \\
\text { transaksi }\end{array}$ & $\begin{array}{l}\text { Menampilkan } \\
\text { halaman transaksi } \\
\text { dan booking } \\
\text { lapangan }\end{array}$ & $\begin{array}{l}\text { Sistem berhasil } \\
\text { menampilkan } \\
\text { halaman transaksi } \\
\text { dan booking } \\
\text { lapangan }\end{array}$ & Valid \\
\hline 16 & $\begin{array}{l}\text { Menu } \\
\text { halaman } \\
\text { transaksi }\end{array}$ & $\begin{array}{l}\text { Klik menu } \\
\text { transaksi }\end{array}$ & $\begin{array}{l}\text { Menampilkan } \\
\text { data transaksi }\end{array}$ & $\begin{array}{l}\text { Sistem berhasil } \\
\text { menambah data } \\
\text { transaksi }\end{array}$ & Valid \\
\hline 17 & $\begin{array}{l}\text { Tambah data } \\
\text { transaksi }\end{array}$ & $\begin{array}{l}\text { Klik menu } \\
\text { add new }\end{array}$ & $\begin{array}{l}\text { Masukkan data } \\
\text { transaksi }\end{array}$ & $\begin{array}{l}\text { Sistem berhasil } \\
\text { menyimpan data } \\
\text { transaksi }\end{array}$ & Valid \\
\hline 18 & $\begin{array}{l}\text { Menu lihat } \\
\text { data transaksi }\end{array}$ & $\begin{array}{l}\text { Klik menu } \\
\text { view }\end{array}$ & $\begin{array}{l}\text { Menampilkan } \\
\text { data transaksi }\end{array}$ & $\begin{array}{l}\text { Sistem berhasil } \\
\text { menampilkan data } \\
\text { transaksi }\end{array}$ & Valid \\
\hline 19 & $\begin{array}{l}\text { Edit data } \\
\text { transaksi }\end{array}$ & $\begin{array}{l}\text { Klik menu } \\
\text { edit }\end{array}$ & $\begin{array}{l}\text { Mengubah data } \\
\text { transaksi }\end{array}$ & $\begin{array}{l}\text { Sistem berhasil } \\
\text { mengubah data } \\
\text { transaksi }\end{array}$ & Valid \\
\hline 20 & $\begin{array}{l}\text { Hapus data } \\
\text { transaksi }\end{array}$ & $\begin{array}{l}\text { Klik menu } \\
\text { delete }\end{array}$ & $\begin{array}{l}\text { Menghapus data } \\
\text { transaksi }\end{array}$ & $\begin{array}{l}\text { Sistem berhasil } \\
\text { menghapus data } \\
\text { transaksi }\end{array}$ & Valid \\
\hline 21 & $\begin{array}{l}\text { Menu } \\
\text { halaman } \\
\text { booking } \\
\text { lapangan }\end{array}$ & $\begin{array}{l}\text { Klik menu } \\
\text { booking } \\
\text { lapangan }\end{array}$ & $\begin{array}{l}\text { Menampilkan } \\
\text { data booking } \\
\text { lapangan }\end{array}$ & $\begin{array}{l}\text { Sistem berhasil } \\
\text { menambah data } \\
\text { booking lapangan }\end{array}$ & Valid \\
\hline
\end{tabular}




\begin{tabular}{|c|c|c|c|c|c|}
\hline 22 & $\begin{array}{l}\text { Tambah data } \\
\text { booking } \\
\text { lapangan }\end{array}$ & $\begin{array}{l}\text { Klik menu } \\
\text { add new }\end{array}$ & $\begin{array}{l}\text { Masukkan data } \\
\text { booking lapangan }\end{array}$ & $\begin{array}{l}\text { Sistem berhasil } \\
\text { menyimpan data } \\
\text { booking lapangan }\end{array}$ & Valid \\
\hline 23 & $\begin{array}{l}\text { Menu lihat } \\
\text { data booking } \\
\text { lapangan }\end{array}$ & $\begin{array}{l}\text { Klik menu } \\
\text { view }\end{array}$ & $\begin{array}{l}\text { Menampilkan } \\
\text { data booking } \\
\text { lapangan }\end{array}$ & $\begin{array}{l}\text { Sistem berhasil } \\
\text { menampilkan data } \\
\text { booking lapangan }\end{array}$ & Valid \\
\hline 24 & $\begin{array}{l}\text { Edit data } \\
\text { booking } \\
\text { lapangan }\end{array}$ & $\begin{array}{l}\text { Klik menu } \\
\text { edit }\end{array}$ & $\begin{array}{l}\text { Mengubah data } \\
\text { booking lapangan }\end{array}$ & $\begin{array}{l}\text { Sistem berhasil } \\
\text { mengubah data } \\
\text { booking lapangan }\end{array}$ & Valid \\
\hline 25 & $\begin{array}{l}\text { Hapus data } \\
\text { booking } \\
\text { lapangan }\end{array}$ & $\begin{array}{l}\text { Klik menu } \\
\text { delete }\end{array}$ & $\begin{array}{l}\text { Menghapus data } \\
\text { booking lapangan }\end{array}$ & $\begin{array}{l}\text { Sistem berhasil } \\
\text { menghapus data } \\
\text { booking lapangan }\end{array}$ & Valid \\
\hline 26 & $\begin{array}{l}\text { Menu data } \\
\text { report }\end{array}$ & $\begin{array}{l}\text { Klik menu } \\
\text { report }\end{array}$ & $\begin{array}{l}\text { Menampilkan } \\
\text { halaman laporan } \\
\text { pendapatan dan } \\
\text { laporan } \\
\text { pengeluaran }\end{array}$ & $\begin{array}{l}\text { Sistem berhasil } \\
\text { menampilkan } \\
\text { halaman laporan } \\
\text { pendapatan dan } \\
\text { laporan } \\
\text { pengeluaran }\end{array}$ & Valid \\
\hline 27 & $\begin{array}{l}\text { Menu } \\
\text { halaman } \\
\text { laporan } \\
\text { pendapatan }\end{array}$ & $\begin{array}{l}\text { Klik menu } \\
\text { laporan } \\
\text { pendapatan }\end{array}$ & $\begin{array}{l}\text { Menampilkan } \\
\text { data laporan } \\
\text { pendapatan }\end{array}$ & $\begin{array}{l}\text { Sistem berhasil } \\
\text { menambah data } \\
\text { laporan } \\
\text { pendapatan }\end{array}$ & Valid \\
\hline 28 & $\begin{array}{l}\text { Download } \\
\text { report } \\
\text { pendapatan }\end{array}$ & $\begin{array}{l}\text { Klik menu } \\
\text { download } \\
\text { report }\end{array}$ & $\begin{array}{l}\text { Download data } \\
\text { pendapatan }\end{array}$ & $\begin{array}{lr}\text { Sistem berhasil } \\
\text { download data } \\
\text { pendapatan }\end{array}$ & Valid \\
\hline 29 & $\begin{array}{l}\text { Menu } \\
\text { halaman } \\
\text { laporan } \\
\text { pengeluaran }\end{array}$ & $\begin{array}{l}\text { Klik menu } \\
\text { laporan } \\
\text { pengeluaran }\end{array}$ & $\begin{array}{l}\text { Menampilkan } \\
\text { data laporan } \\
\text { pengeluaran }\end{array}$ & $\begin{array}{l}\text { Sistem berhasil } \\
\text { menambah data } \\
\text { laporan } \\
\text { pengeluaran }\end{array}$ & Valid \\
\hline 30 & $\begin{array}{l}\text { Download } \\
\text { report } \\
\text { pengeluaran }\end{array}$ & $\begin{array}{l}\text { Klik menu } \\
\text { download } \\
\text { report }\end{array}$ & $\begin{array}{l}\text { Download data } \\
\text { pengeluaran }\end{array}$ & $\begin{array}{lr}\text { Sistem berhasil } \\
\text { download data } \\
\text { pengeluaran }\end{array}$ & Valid \\
\hline 31 & $\begin{array}{l}\text { Halaman } \\
\text { dasboard user }\end{array}$ & $\begin{array}{l}\text { Klik menu } \\
\text { dashboard }\end{array}$ & \begin{tabular}{l}
\multicolumn{2}{l}{ Menampilkan } \\
home, history \\
booking, profil, \\
sign out
\end{tabular} & $\begin{array}{l}\text { Sistem berhasil } \\
\text { menampilkan } \\
\text { home, history } \\
\text { booking, profil, } \\
\text { sign out }\end{array}$ & Valid \\
\hline 32 & $\begin{array}{l}\text { Halaman } \\
\text { utama user }\end{array}$ & $\begin{array}{l}\text { Klik menu } \\
\text { home }\end{array}$ & $\begin{array}{l}\text { Menampilkan } \\
\text { menu lapangan }\end{array}$ & $\begin{array}{l}\text { Sistem berhasil } \\
\text { menampilkan } \\
\text { menu lapangan }\end{array}$ & valid \\
\hline 33 & $\begin{array}{l}\text { Booking } \\
\text { lapangan }\end{array}$ & $\begin{array}{l}\text { Klik menu } \\
\text { lapangan }\end{array}$ & $\begin{array}{l}\text { Melakukan } \\
\text { booking lapangan }\end{array}$ & $\begin{array}{l}\text { Sistem berhasil } \\
\text { menyimpan data } \\
\text { pesanan }\end{array}$ & valid \\
\hline 34 & $\begin{array}{l}\text { Halaman } \\
\text { history } \\
\text { booking }\end{array}$ & $\begin{array}{l}\text { Klik menu } \\
\text { history } \\
\text { booking }\end{array}$ & $\begin{array}{l}\text { Menampilkan } \\
\text { halaman history } \\
\text { booking }\end{array}$ & $\begin{array}{l}\text { Sistem berhasil } \\
\text { menampilkan } \\
\text { halaman history } \\
\text { booking }\end{array}$ & valid \\
\hline 35 & $\begin{array}{l}\text { Halaman } \\
\text { pembayaran }\end{array}$ & $\begin{array}{l}\text { Klik menu } \\
\text { bayar }\end{array}$ & $\begin{array}{l}\text { Melakukan } \\
\text { pembayaran }\end{array}$ & $\begin{array}{l}\text { Sistem berhasil } \\
\text { melakukan } \\
\text { pembayaran }\end{array}$ & valid \\
\hline 36 & $\begin{array}{l}\text { Halaman } \\
\text { profil }\end{array}$ & $\begin{array}{l}\text { Klik menu } \\
\text { profil }\end{array}$ & $\begin{array}{l}\text { Memasukkan } \\
\text { foto profil, }\end{array}$ & $\begin{array}{l}\text { Sistem berhasil } \\
\text { memasukkan foto }\end{array}$ & valid \\
\hline
\end{tabular}




\begin{tabular}{|l|l|l|l|l|l|}
\hline & & & $\begin{array}{l}\text { menampilkan } \\
\text { foto profil, dan } \\
\text { menampilkan } \\
\text { data user }\end{array}$ & $\begin{array}{l}\text { profil, } \\
\text { menampilkan foto } \\
\text { profil, dan } \\
\text { menampilkan data } \\
\text { user }\end{array}$ & \\
\hline 37 & Halaman chat & $\begin{array}{l}\text { Klik menu } \\
\text { chat }\end{array}$ & $\begin{array}{l}\text { Melakukan live } \\
\text { chat }\end{array}$ & $\begin{array}{l}\text { Sistem berhasil } \\
\text { melakukan live } \\
\text { chat }\end{array}$ & Valid \\
\hline
\end{tabular}

\subsection{Interface}

\section{जी}

Login

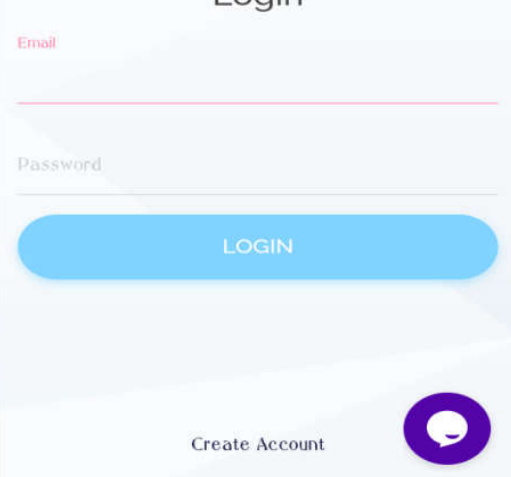

Gambar 5. Halaman Login

Gambar 5. Halaman login pelanggan, menampilkan halaman yang digunakan oleh pelanggan untuk login aplikasi. pelanggan memasukkan username dan password kemudian klik Login untuk masuk kedalam halaman utama. Jika login gagal, maka masukkan kembali username dan password dengan benar.

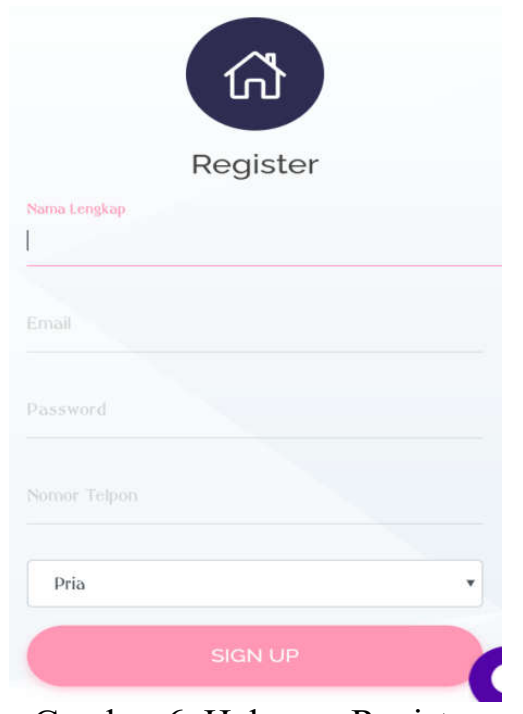

Gambar 6. Halaman Register

Gambar 6. halaman register pelanggan menampilkan menu untuk melakukan registrasi yaitu nama lengkap, email, password, nomor telepon, dan jenis kelamin. Halaman ini digunakan 
untuk pelanggan baru yang belum memiliki email dan password untuk melakukan login aplikasi.

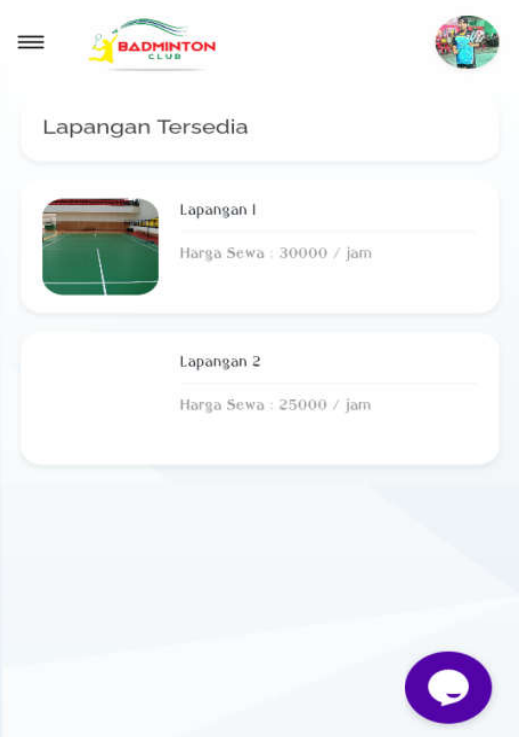

Gambar 7. Halaman Utama Pelanggan

Gambar 7 halaman utama pelanggan, Ketika login telah berhasil maka pelanggan akan masuk ke halaman utama. Halaman utama pelanggan menampilkan informasi lapangan yang tersedia yang berisi nama lapangan, gambar lapangan, dan harga lapangan. Untuk melakukan pemesanan klik nama lapangan maka akan dilanjutkan kehalaman selanjutnya.

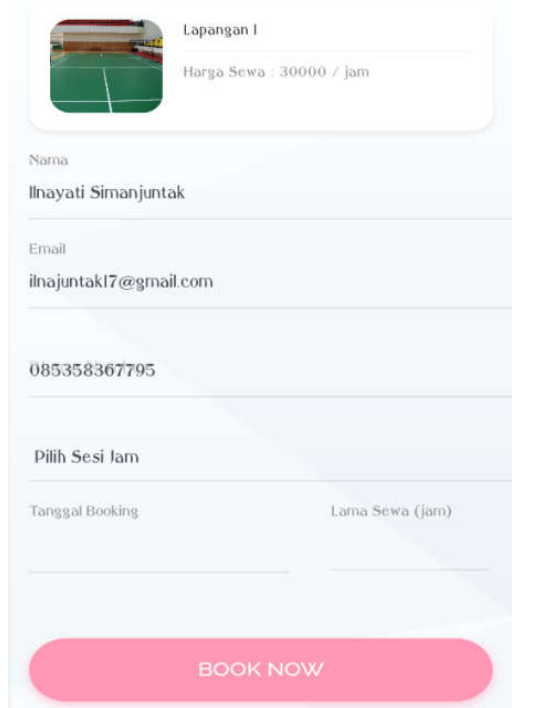

Gambar 8. Halaman Pemesanan Pelanggan

Gambar 8 menampilkan menu yang digunakan untuk melanjutkan proses pemesanan yaitu tanggal booking, lama sewa, dan book now. Halaman ini juga menampilkan informasi nama lapangan, harga sewa, nama lengkap, email, dan nomor telepon. Untuk melakukan pemesanan pilih sesi jam, tanggal, bulan, dan tahun terlebih dahulu, lalu pilih lama sewa lapangan yang akan digunakan, setelah selsai mengisi data maka klik book now. 


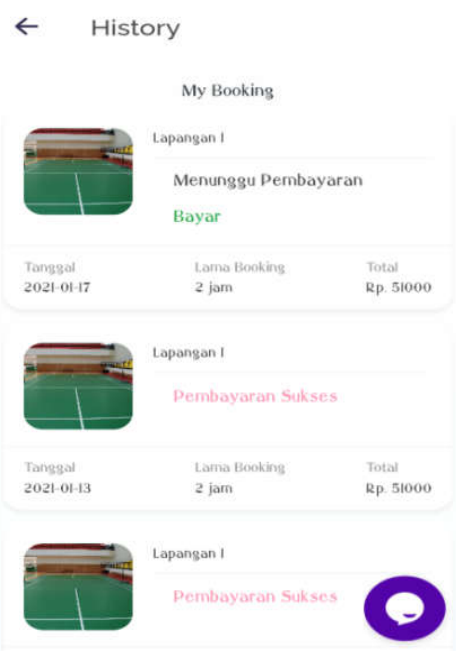

Gambar 9. Halaman Riwayat Pemesanan

Gambar 9 merupakan halaman yang digunakan untuk menampilkan riwayat pemesanan lapangan yang telah dilakukan oleh pelanggan baik yang sudah dibayar maupun yang belum dibayar. Untuk melanjutkan pembayaran klik menu bayar maka akan diteruskan ke halaman pembayaran.

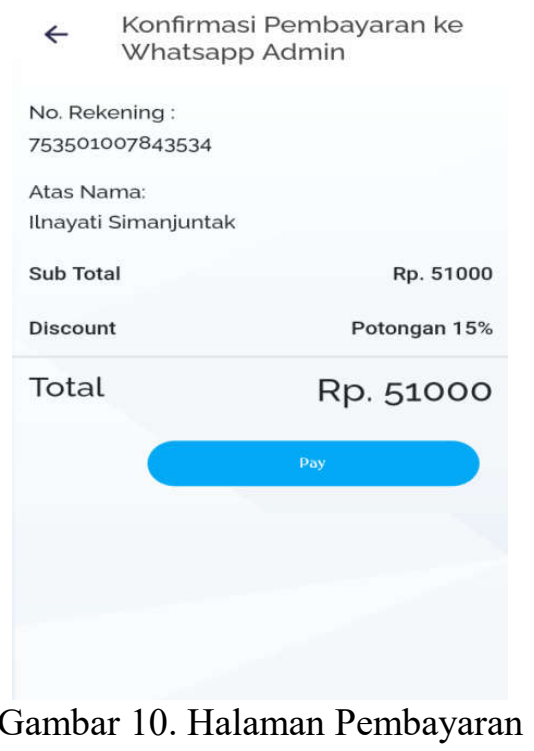

Gambar 10 setelah selesai melakukan pemesanan maka akan dilanjutkan kehalaman pembayaran yang berisi informasi nomor rekening, nama rekening, sub total, discount, dan total. Untuk melakukan transaksi pembayaran caranya klik Pay maka pembayaran akan di proses. 


\section{$\leftarrow$ Profil}

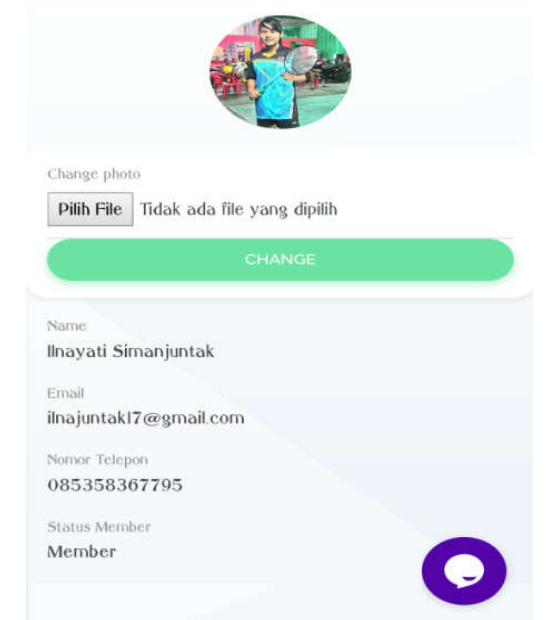

Gambar 11. Halaman Profil Pengguna

Gambar 11 adalah halaman yang digunakan pelanggan untuk mengubah status non member menjadi member dan digunakan untuk upload foto profil dengan cara klik pilih file dan setelah berhasil memilih foto kemudian klik change maka foto profil akan ditampilkan. Halaman ini juga menampilkan informasi data diri dari pelanggan yaitu nama, email, nomor telepon dan status member.

\section{KESIMPULAN}

Berdasarkan penelitian yang telah dilakukan, dapat diambil kesimpulan sebagai berikut hasil rancang bangun aplikasi penyewaan lapangan bulutangkis pada GOR AUB menggunakan Flowchart, UML (Unified Modeling Language) yang tediri dari Usecase Diagram, Activity Diagram, Sequence Diagram, Class Diagram, dan Entity Relationship Diagram. Sedangkan untuk metode pengembangan sistem menggunakan Metode Waterfall. Adanya Aplikasi Penyewaan Lapangan Bulutangkis pada GOR AUB memberikan media baru bagi pelanggan dalam menyediakan informasi ketersediaan lapangan bulutangkis yang disewakan. Selain itu dapat melakukan transaksi penyewaan tersebut. Sehingga dapat memudahkan pelanggan untuk mendapatkan informasi tersebut. Pengembangan sistem menggunakan bahasa pemrograman PHP dan Java, database menggunakan MySQL, aplikasi pendukung Android Studio Versi 3.0.1 dan Notepad++. Sistem ini bisa melakukan pengolahan data penyewaan, pembayaran, pengolahan data member dan pengolahan data transaksi.

\section{SARAN}

Aplikasi Penyewaan Lapangan Bulutangkis pada GOR AUB ini masih dapat dikembangkan lebih lanjut dengan menambahkan informasi alamat yaitu dengan menambahkan informasi lokasi langsung dari google map agar memudahkan pelanggan untuk datang ke gedung olahraga AUB Surakarta. Menambahkan laporan lapangan kosong supaya pengola mengetahui jadwal yang belum terpakai. Menambahkan metode pembayaran e-payment pada aplikasi. Memberikan filter pada lapangan atau jadwal yang telah terpakai.

\section{DAFTAR PUSTAKA}

[1] Safaat, N. (2012). Android Pemrograman Aplikasi Mobile Smartphone dan Tablet PC Berbasis Android. Bandung: Informatika Bandung 
[2] Sugiyono. (2013). Metode Penelitian Kuanitatif, Kualitatif, dan R\&D. Bandung: Alfabeta. CV

[3] Pressman, R. S. (2001). Rekayasa Perangkat Lunak Pendekatan Praktisi. Yogyakarta: Andi.

[4] Supardi, I. Y. (2017). Koleksi Program Tugas Akhir dan Skripsi Dengan Android. Jakarta: Elex Media Komputindo.

[5] Shalahuddin, M. D. (2015). Rekayasa Perangkat Lunak Terstruktur dan Berorientasi Objek. Bandung: Informatika Bandung. 